\title{
EFFECTS OF MILKING FREQUENCY ON MILKYIELD, DRY MATTER INTAKE AND EFFICIENCY OF FEED UTILIZATION INWAD GOATS
}

\author{
EFECTOS DE LA FRECUENCIA DE ORDEÑO EN LA PRODUCCIÓN DE LECHE, \\ CONSUMO DE MATERIA SECA Y EFICIENCIA DEL ALIMENTO EN CABRAS WAD
}

\author{
Williams, T.J. ${ }^{1 *}$, Osinowo, O.A. ${ }^{3}$, Smith, O.F. ${ }^{1}$, James, I.J. ${ }^{1}$, Ikeobi, C.O.N. ${ }^{2}$, \\ Onagbesan, O.M. ${ }^{1}$, Shittu, O.O. ${ }^{3}$ and Solola, F.T. ${ }^{1}$
}

\begin{abstract}
${ }^{1}$ Department of Animal Physiology. University of Agriculture. Abeokuta, Ogun State. Nigeria. *tolwilly@gmail.com

${ }^{2}$ Department of Animal Breeding and Genetics. University of Agriculture. Abeokuta, Ogun State. Nigeria. ${ }^{3}$ Institute of Food Security. Environmental Resources and Agricultural Research. University of Agriculture. Abeokuta. Ogun State. Nigeria.
\end{abstract}

\section{Additional KeYWORDS}

Hand milking.

\section{SUMMARY}

Effects of milking frequency on milk yield, dry matter intake (DMI) and effeciency of feed utilization for milk production was investigated in West African Dwarf (WAD) goats at Abeokuta in the humid zone of South Western Nigeria. Seventeen WAD goats were fed a ration comprising (on dry matter basis) $50 \%$ grass (Pennisetum purpureum) and $50 \%$ concentrate $(17 \%$ crude protein) at $5 \%$ body weight. The study involved hand milking once (at $6.00 \mathrm{am}$ ), twice (at $6.00 \mathrm{am}$ and $6.00 \mathrm{pm}$ ) and thrice (at $6.00 \mathrm{am}, 2.00 \mathrm{pm}$ and $10.00 \mathrm{pm}$ ) daily for 21 and 35 days covering two periods, from JuneOctober 2004 (Trial I) and April-July 2005 (Trial II) in a randomised complete block design. Kids were separated from their dams at day 14 and artificially reared. Compared to twice $(2 x)$ daily milking $(322.2$ $\mathrm{mL} /$ day), the milk yield for once $(1 \mathrm{x})$ daily milking $(181.5 \mathrm{~mL} /$ day $)$ was significantly $(p<0.001)$ lowered by $43.7 \%$. Milk yield for thrice (3x) daily milking ( $334.8 \mathrm{~mL} /$ day) was however, higher by $3.8 \%$ compared to $2 \mathrm{x}$. Twice and thrice daily milking were not significantly different $(p>0.05)$. As lactation progressed, day of lactation significantly $(p<0.001)$ affected milk yield and declined by $2.5 \mathrm{~mL}$ for each additional day of lactation. Dry matter intake (DMI) significantly $(p<0.05)$ increased with milking frequency. The DMI was $6.7 \%$ higher in trial I compared to trial II. Day of lactation had significant effect $(p<0.001)$

Recibido: 4-11-11. Aceptado: 23-2-12.

\section{PaLABRAS CLAVE ADICIONALES \\ Ordeño manual.}

on DMI increasing by $3.73 \mathrm{~g}$ for each additional day of lactation. The DMI for $2 x$ and $3 x$ daily milkings were however not different $(p>0.05)$. Milking frequency had significant effect $(p<0.001)$ on efficiency of feed utilization for milk production. The findings of this study indicate that milk yield and DMI increase with milking frequency. Therefore, it is concluded that twice daily milking of WAD goats optimises milk yield.

\section{RESUMEN}

En Abeokuta, en la zona húmeda de Nigeria, se estudiaron los efectos de la frecuencia de ordeño sobre la producción de leche, la ingestión de materia seca (DMI) y eficiencia de la utilización del alimento en cabras Enanas de Africa Occidental (WAD). Diecisiete cabras WAD fueron alimentadas con una ración compuesta (sobre materia seca) de $50 \%$ de gramíneas (Pennisetum purpureum) y $50 \%$ de concentrado $(17 \%$ de proteína bruta) en la proporción de $5 \%$ del peso corporal. Se realizaron uno (a las 6:00 am), dos (a las 6:00 am y 6:00 pm) y tres (a las 6:00 am, 2:00 pm y 10:00 pm) ordeños diarios durante 21 y 35 días en dos periodos de junio a octubre de 2004 (ensayo I) y de abril a julio de 2005 (ensayo II) en un diseño de bloques completamente al azar. Los chivos fueron separados de sus madres el día 14 
y alimentados con lactancia artificial. Comparado con los dos ordeños $(2 x)$ diarios (322,2 mL/día), el rendimiento de un solo (1x) ordeño $(181,5 \mathrm{~mL} /$ día) fue significtivamente $(p<0,001)$ menor en un $43 \%$. El rendimiento lácteo para tres $(3 x)$ ordeños diarios (334,8 mL/día) fue sin embargo sólo el 3,8\% más elevado que para dos ordeños. Los rendimientos para dos o tres ordeños diarios no fueron diferentes. A medida que la lactación progresaba, el día de lactación afectó de modo significativo $(p<0,001)$ al rendimiento, que disminuyó $2,5 \mathrm{~mL}$ por cada día adicional de lactación. La ingestión de materia seca incrementó $(p<0,05)$ con la frecuencia de ordeño. La DMI fue $6,7 \%$ mayor en el ensayo I respecto del ensayo II. El día de lactación influyó $(p<0,001)$ incrementando la DMI en 3,73 por día adicional. La ingestión de materia seca fue similar con dos o tres ordeños. La frecuencia de ordeño mostró un efecto significativo $(p<0,001)$ sobre la eficiencia de utilización del alimento para la producción de leche. Los hallazgos de este estudio indican que la producción de leche y la DMI aumentan con la frecuencia de ordeño. Por ello, se concluye que la práctica de dos ordeños diarios en las cabras WAD, optimiza el rendimiento lácteo.

\section{INTRODUCTION}

Regular and complete milking is one of the requirements for continuance of lactation. The effect of changes in milking frequency on milk yield varies widely between individual species (Davis et al., 1999). Reducing milking frequency from $2 x$ daily milking to $1 \mathrm{x}$ daily milking decreased milk yield from 7 to $38 \%$ in dairy cows (Stelwagen and Knight, 1997), 15 to $48 \%$ in ewes (Negrao et al., 2001), 6 to 35\% in dairy goats (Capote et al., 1999) and increased the rate of loss of udder tissue (Carruthers et al., 1993). However increasing milking frequency from $2 \mathrm{x}$ to $3 \mathrm{x}$ increased milk yield by 7 to $20 \%$ (Stelwagen, 2001). The mechanisms responsible for the increase in milk yield have not been identified but some researches suggest an increase in mammary epithelial cell (MEC) number (Hale et al., 2003), reduction in MEC apoptosis (Li et al., 1999), increased cell activity (Knight et al., 1992) and frequent removal of feedback inhibitor of lactation (FIL) from the glands (Erdman and Varner, 1995).

Milking frequency stimulates mammary functions and milk synthesis is manipulated specifically by a non-invasive method.These increases are achieved with little loss of body weight or condition, the extra nutrient requirement being met by an increased feed intake. The aim of this study therefore, is to investigate the effects of milking frequency on milk yield, dry matter intake and efficiency of feed utilization for milk production in West African Dwarf goats.

\section{MATERIALS AND METHODS}

\section{HERD MANAGEMENT AND EXPERIMENTAL PROCEDURE}

The research was conducted at the Goat Unit of the College of Animal Science and Livestock Production Teaching and Research Farm, University of Agriculture, Abeokuta, Nigeria. The animals used for the experiment were part of the goat breeding flock of the College of Animal Science and Livestock Production at the University farm. They were managed under intensive system with zero grazing, housed in cross-ventilated pens with slatted flour and had free access to water. The does were naturally mated and were checked 18-21 days later for nonreturns to oestrus (conception). The trial was conducted from June to November 2004 (Trial 1) and April to July 2005 (Trial 2) respectively. Efficiency of feed utilization for milk production was determined by dividing the milk yield (quantity of milk produced) by dry matter intake (feed consumed) daily.

The animals were fed at $5 \%$ body weight consisting of roughage (elephant grass) and concentrate in the ratio of 50:50 (offered on dry matter basis). The dry matter intake was deducted as the difference between quantities offered and left over. Freshly cut elephant grass (Pennisetum purpureum) was chopped and offered to the animals. The composition of the elephant grass and 
Table I. Proximate nutrient composition of elephant grass (per 100 g). (Composición nutritiva de Pennisetum purpureum).

\begin{tabular}{lcc}
\hline Composition & Fresh & Hay \\
\hline Water & 77.8 & 10.9 \\
Crude protein & 1.0 & 8.2 \\
Ether extract & 0.5 & 1.8 \\
Crude fibre & - & 34.0 \\
Ash & 3.1 & 20.5 \\
Total carbohydrate & 17.6 & 68.6 \\
\hline
\end{tabular}

Source: Duke (1983).

concentrate is shown in tables I and II respectively.

\section{DATA COLLECTION AND ANALYSIS}

Kids were allowed to stay with their dams for 14 days and milking commenced from the third week of lactation of each animal. kids were then artificially reared. Animals were milked for 21 days in the first trial. The animals were re-mated and milking was repeated for 35 days for the second

Table II. Gross composition of concentrate fed to West African Dwarfgoats. (Composición del concentrado suministrado a las cabras West African Dwarf).

\begin{tabular}{lc}
\hline Ingredients & \% Composition \\
\hline Maize & 5 \\
Dry brewers grain (BDG) & 35 \\
Palm kernel cake (PKC) & 18 \\
Wheat offal (WO) & 40 \\
Bone meal (BM) & 1 \\
Common salt & 1 \\
Total & 100 \\
& \\
Calculated analysis & \\
Crude protein & 16.84 \\
Crude fibre & 12.66 \\
Ether extract & 4.78 \\
Calcium & 0.52 \\
Available phosphorus & 0.34 \\
Metabolizable energy (kcal/kg) & 2004.2 \\
& \\
\hline
\end{tabular}

Table III. Milking protocols. (Protocolo de ordeño).

\begin{tabular}{|c|c|c|}
\hline $\begin{array}{c}\text { Milking } \\
\text { frequency }\end{array}$ & $\begin{array}{l}\text { Milking } \\
\text { interval }\end{array}$ & $\begin{array}{c}\mathrm{N}^{\circ} \text { animals/ } \\
\text { treatment }\end{array}$ \\
\hline 1 & $6.00 \mathrm{am}$ & 7 does \\
\hline 2 & 6.00am \& 6.00pm & 5 does \\
\hline 3 & 6.00am, 2.00pm \& 10.00pm & 5 does \\
\hline
\end{tabular}

trial. Dams were hand milked three times daily (table III) and the milk was recorded daily in mL. Data collected were subjected to least square analysis (SYSTAT, 1992) in a randomised complete block design. Efficiency of feed utilization for milk production was analysed using the model below:

$$
Y_{i j k}=\mu+R_{i}+P_{j}+R P_{i j}+D+E_{i j k}
$$

where:

$Y_{i j k}=$ Efficiency of feed utilization for milk production $\mu=$ The overall mean,

$\mathrm{R}_{\mathrm{i}}=$ The fixed effect of the $\mathrm{i}^{\mathrm{i}}$ milking frequency $(\mathrm{i}=1$ 3),

$P=$ The fixed effect of the $j^{\text {th }}$ trial number $(j=1-2)$, $\mathrm{D}=$ Day of lactation as co-variate,

$E_{i j k}=$ Random error associated with each record.

\section{RESULTS}

\section{MILKSECRETION}

The milk yield for $1 \mathrm{x}, 2 \mathrm{x}$ and $3 \mathrm{x}$ daily milking were 181.5, 322.2 and $334.8 \mathrm{~mL} /$ day/ goat respectively. The analysis of the results (table IV) showed that milking frequency had significant effect $(p<0.001)$ on daily milk yield. The milk yield for $1 \mathrm{x}$ daily milking (181.5 mL/day) was significantly lower ( $\mathrm{p}<0.001)$ by $43.67 \%$ and $45.79 \%$ to $2 \times(322.2$ $\mathrm{mL} /$ day) and $3 \times(334.8 \mathrm{~mL} /$ day $)$ daily milking respectively, though the latter two were not significantly different $(p>0.05)$. Day of lactation had significant effect $(p<0.001)$ on milk yield. Milk yield declined from the $6^{\text {th }}$ day of milking averagely by $2502 \mathrm{~mL} /$ day/ goat for each additional day of lactation. 
Table IV. Effects of milking frequency and trial number on milk yield ( $\mathrm{ml} /$ day) in West African Dwarf goats. (Efecto de la frecuencia de ordeño y del ensayo sobre el rendimiento lechero en cabras West African Dwarf).

\begin{tabular}{lcccc}
\hline \multicolumn{4}{c}{ Milking frequency } & \multirow{2}{*}{ Mean \pm SEM } \\
& 1 & 2 & 3 & \\
\hline I (June-November, 2004) & $199.4 \pm 10.2^{\mathrm{c}}$ & $252.5 \pm 12.4^{\mathrm{b}}$ & $299.0 \pm 12.6^{\mathrm{b}}$ & $250.3 \pm 6.9$ \\
II (April-July, 2005) & $163.6 \pm 6.9^{\mathrm{d}}$ & $391.9 \pm 7.9^{\mathrm{a}}$ & $370.6 \pm 7.8^{\mathrm{a}}$ & $308.7 \pm 4.4$ \\
Mean \pm SEM & $181.5 \pm 6.1$ & $322.2 \pm 7.3$ & $334.8 \pm 7.4$ & - \\
\hline
\end{tabular}

abcdMeans with different superscripts differ significantly $(p<0.05)$.

\section{DRY MATTER INTAKE}

Similarly milking frequency had significant effect (table $\mathbf{V}$ ) on dry matter intake $(\mathrm{p}<0.05)$. Dry matter intake for $1 \mathrm{x}, 2 \mathrm{x}$ and $3 \mathrm{x}$ daily milking were $749.1 \mathrm{~g} / \mathrm{goat}, 772.2 \mathrm{~g} / \mathrm{goat}$ and $800.0 \mathrm{~g} /$ goat per day respectively over the two trial periods. The dry matter intake for $1 \mathrm{x}$ daily milking was significantly lower $(\mathrm{p}<0.01)$ compared to $2 \mathrm{x}$ and $3 \mathrm{x}$ daily milking. However, $2 \mathrm{x}$ and $3 \mathrm{x}$ daily milking were not significantly different $(p>0.05)$. Day of lactation also had significant effect $(\mathrm{p}<0.001)$ on dry matter intake. Intake increased by $3733 \mathrm{~g} /$ day/goat for each additional day of lactation.

\section{EFFICIENCY OF FEED UTILIZATION FOR MILK PRODUCTION}

The result showed that milking frequency had significant effect $(p<0.001)$ on efficiency of feed utilization for milk production (figu- re 1). Efficiency of feed utilization for milk production for $1 \mathrm{x}, 2 \mathrm{x}$ and $3 \mathrm{x}$ daily milking were $0.237,0.412$ and 0.431 respectively. Also efficiency of feed utilization for milk production increased with increase in milking frequency. Efficiency of feed utilization for $3 \mathrm{x}$ daily milking was significantly higher $(\mathrm{p}<0.01)$ than $2 \mathrm{x}$. Twice daily milking was also significantly higher $(\mathrm{p}<0.01)$ than $1 \mathrm{x}$ daily milking.

There was significant difference $(p<0.001)$ between the two trial periods. Efficiency of feed utilization for milk production in trial 1 was 0.313 while it was 0.406 in trial 2 . Also there was a significant interaction $(p<0.001)$ between milking frequency and efficiency of feed utilization for milk production. There was significant effect of day of lactation on efficiency of feed utilization for milk production $(\mathrm{p}<0.001)$.

Table $\boldsymbol{V}$. Effects of milking frequency and trial number on dry matter intake (g/day) in West African Dwarf goats. (Efecto de la frecuencia de ordeño y del ensayo sobre la ingestión de materia seca ( $g / d i ́ a)$ en cabras West African Dwarf).

\begin{tabular}{lcccc}
\hline & \multicolumn{3}{c}{ Milking frequency } & Mean \pm SEM \\
& 1 & 2 & 3 & \\
\hline I (June-November, 2004) & $855.9 \pm 18.6^{\mathrm{a}}$ & $691.0 \pm 22.7^{\mathrm{bc}}$ & $855.0 \pm 23.0^{\mathrm{a}}$ & $800.7 \pm 12.6$ \\
II (April-July, 2005) & $642.2 \pm 12.5^{\mathrm{c}}$ & $853.4 \pm 14.4^{\mathrm{a}}$ & $745.0 \pm 14.3^{\mathrm{b}}$ & $746.9 \pm 8.0$ \\
Mean \pm SEM & $749.1 \pm 11.1$ & $772.2 \pm 13.4$ & $800.0 \pm 13.5$ & - \\
\hline
\end{tabular}

abcMeans with different superscripts differ significantly $(p<0.01)$. 


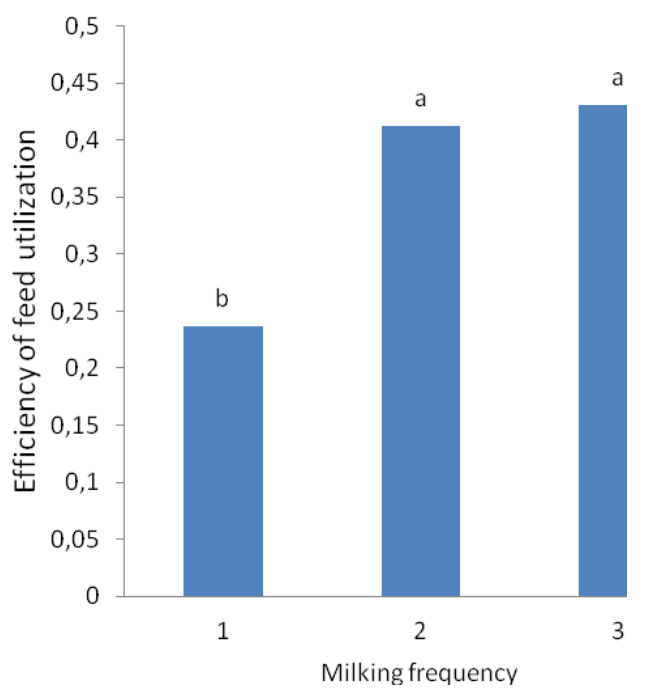

Figure 1. Efficiency of feed utilization for milkproduction in West African Dwarfgoats. $a, b$-Bars with different letters are significantly different $(p<0.01)$. (Eficiencia de la utilización de piensos para la producción de leche en cabras West African Dwarf. a,b-Letras diferentes indican diferencias significativas $(p<0,01))$.

\section{DISCUSSION}

The result of the study clearly showed the yield promoting effect of milking frequency in West African Dwarf goats. The result agree with several authors who reported significant increase in milk yield with increased milking frequency (Pearson et al., 1979; Poole, 1982; Archer, 1983; Stelwagen, 2001; Salama et al., 2003; VanBaale et al., 2005). The mechanisms responsible for the increase in milk yield include, increase in mammary epithelial cell (MEC) number, (Hale et al., 2003), reduction in MEC apoptosis (Li et al., 1999), increased cell activity (Knight et al., 1992) and frequent removal of FIL from the glands.

Milk yield for $1 \mathrm{x}$ daily milking was significantly lowered $(\mathrm{p}<0.001)$ by $43.67 \%$ and $45.79 \%$ compared with $2 x$ and $3 x$ daily milking respectively. These reductions were greater than the values previously reported in Canarian goats $(6 \%)$ by Capote et al. (1999); Murciano-Granadina goats (18\%) by Salama et al. (2003); and Alpine goats (36\%) by Mocquot (1978). Wilde and Knight (1990) also reported a loss of $26 \%$ in Saanen goats in a short-term experiment in early lactation, while losses ranged between 6 and $7 \%$ in Damascus goats during middle and late lactation respectively (Papachristoforou et al., 1982).

The wide variation in yield losses during $1 \mathrm{x}$ milking reported by different authors may be due to differences in breed, lactation stage, level of production, duration of $1 \mathrm{x}$ milking and nutrition level. Moreover, the increase in the concentration of the putative feedback inhibitor of lactation (FIL), synthesized by the mammary gland (Wilde et al., 1995) and intramammary pressure (Peaker, 1990) may cause the decrease in milk synthesis in 1x daily milked goats. In addition, the loss of tight junction (TJ) integrity after about $20 \mathrm{~h}$ of milk accumulation may play a role in milk yield losses in once milking (Stelwagen et al., 1994a). It should also be noted that when less frequent milking is prolonged, the decrease in milk yield is sustained by sequential developmental adaptations, initially as a downregulation of cellular differentiation (Wilde et al., 1987) and later as a net loss in mammary cell number via apoptosis (Li et al., 1999).

The non-significant difference $(\mathrm{p}>0.05)$ observed with $2 \mathrm{x}$ and $3 \mathrm{x}$ daily milking in this study completely deviated from results published by other authors. While Stelwagen (2001) reported that changing milking frequency from $2 \mathrm{x}$ to $3 \mathrm{x}$ in cattle resulted in 18\% increase, Erdman and Varner (1995); Jurjanz et al. (1993) and Van der Iest and Hilerton (1989) reported an increase of 10$20 \%$ in cows when daily milking frequency was changed from $2 \mathrm{x}$ to $3 \mathrm{x}$. The disparity in the result and in this study might be attributed to the breed of goat used, size of data and the plane of nutrition the animals were placed.

Day of lactation had significant effect 
$(\mathrm{p}<0.001)$ on milk yield. Yield declined by 2.5 $\mathrm{mL}$ for each additional day of lactation. This result agrees with that of Chamberlain (1989) who reported that milk production in cows gradually declines after reaching its peak. This decline (Linzell, 1966) was mainly due to the loss of secretory tissue and decrease in rate of secretion per cell. Similarly, in nonpregnant cows, the decline in milk yield after peak lactation was very gradual, with each month's yield being $95 \%$ of preceding month (Chamberlain, 1989).

The study revealed that milking frequency had significant $(p<0.05)$ effect on dry matter intake. It showed that there is a positive correlation between milking frequency and dry matter intake. This result agrees with that by Bar-Peled et al. (1995) who reported that cows milked 6x daily consumed more dry matter than did cows milked 3x daily. Similarly, Barnes et al.(1990) and Royle et al. (1992) stated that a measurable increase in dry matter intake in cows accompanied the rise in milk production from higher milking frequencies.

It was noticeable that as the day of lactation progressed, most of the animals did not gain weight. In fact, some actually lost weight during the milking period (especially animals on $3 \mathrm{x}$ daily milking) indicating higher demands for dry matter intake at higher milking frequency. This result corroborates the findings of Bar-Peled et al. (1995) that increased dry matter intake by cows milked $6 x$ daily did not compensate for the increased energy demands, thus these cows lost BW, had a lower body condition scores during the initial lactation period and displayed a longer recovery period than did cows milked $3 x$ daily. Barnes et al. (1990) also reported that cows milked $3 x$ daily did tend $(p<0.1)$ to be lighter than their counterparts milked $2 x$ daily during lactation. They observed further, that dry matter intake increased by approximately $15 \%$ and cows on $2 \mathrm{x}$ and $3 \mathrm{x}$ daily milking consumed 10 and $11 \%$ more dry matter than controls during lactation respectively.
Although, Amos et al. (1985) reported that increased dry matter intake was too small to be measurable or nonexistent, Pearson et al. (1979) reported that cows milked 3x daily actually had lower dry matter intake than those milked $2 \mathrm{x}$ daily. On the contrary, however, Hansen et al. (1979) and Amos et al. (1985) noted that milking frequency was not associated with a significant change in body weight.

DePeters et al. (1995) reported that milking $3 \mathrm{x}$ daily reduced body weight gains in cows and there was a tendency for goats milked 3x daily to lose weight in the present study. Even though, cows were allowed ad libitum dry matter intake (Barnes et al., 1990), the cows milked 3x daily did not respond to the increased energy demand associated with increased yield by consuming more ration. Thus in agreement with Amos et al. (1985), it appears that increasing milking frequency results in either preferential utilization of nutrients for milk production or a higher rate of tissue catabolism. Blake and Custodio (1984) suggested that increased milk yield and milk yield: feed intake occurs only as long as tissue reserves are able to subsidize the nutrient needed for milk yield.

Day of lactation had significant effect $(p<0.001)$ on dry matter intake increasing by $3.73 \mathrm{~g}$ for each additional day of lactation. These results agree with those of Bell (1995) who reported that the onset of lactation results in a dramatic increase in the requirements of nutrients, for example glucose, amino acids and fatty acids. This increase in requirements is met partly by increased voluntary intake partly by an array of metabolic adaptations. According to Tulloh (1966), changes which are of major importance for the establishment and maintenance of high milk production include hypertrophy of the gastro intestinal tract, increased fatty acid metabolism from adipose tissue and an increased rate of gluconeogenesis.

The study showed that milking fre- 
quency had significant effect $(\mathrm{p}<0.001)$ on efficiency of feed utilization for milk production. The efficient utilization of feed by the animals could be attributed to the breed, physiological status of the animals and the quality of the feed offered. This observation agrees with the findings by Blake and Custodio, (1984) who reported that feed efficiency for milk production depends on diet, environmental factors and on genetic ability of the animal to utilize these inputs to produce milk. Furthermore, White (1989) noted that efficiency of carbohydrate utilization (carbohydrates being the major nutritive portion of ruminant animal feed) can be increased by treatments which encourage the animals to produce propionate rather than acetate or butyrate from carbohydrates. Consequently, if the animal is making more propionate, it will be found to be using its feed more efficiently. The elephant grass offered to the animals was chopped and fresh thereby increasing the surface area of the roughage. This may therefore, contribute to its efficient utilization by the animals. According to Bauman et al. (1979), Tyrrell et al. (1982) and Peel et al. (1983) hormones (e.g. growth hormone, insulin, prolactin) interact to control partitioning of dietary energy into milk and body tissue; this interaction is associated with genetic differences for milk within and between breeds. Consequently the animals could also be under favourable hormonal interaction.

The result also revealed that the higher the milking frequency, the higher the efficiency of feed utilization for milk production [1 $\mathrm{x}(0.237), 2 \mathrm{x}(0.412)$ and $3 \mathrm{x}$

\section{REFERENCES}

Amos, H.E., Kiser, T. and Loewenstein, M. 1985. Influence of milking frequency on productive and reproductive efficiencies of dairy cows. $J$ Dairy Sci, 68: 732.

Archer, P. 1983. Milking three times a day. Milk Marketing Board Report, 34. Farm Management
(0.431)]. Animals on $3 x$ milking frequency utilized their feed better than $2 \mathrm{x}$ and $1 \mathrm{x}$ milking frequencies. This result agrees with those of Barnes et al. (1990) who reported that cows milked 3x daily had efficiency ratios approximately $14 \%$ greater than for cows milked $2 x$. In the present study, animals on $3 x$ daily milking frequency had efficiency ratio of $4.6 \%$ greater than $2 x$ milking frequency. Therefore, animals on $3 x$ milking frequency could have performed better if they were fed according to yield. This could probably explains the non significant difference recorded between $3 x$ and $2 x$ milking frequency in this study.

\section{CONCLUSIONS}

Higher milking frequency increased milk yield in West African Dwarf goats.

One daily milking reduced milk yield by up to $43.67 \%$ and $45.79 \%$ compared with $2 \mathrm{x}$ and $3 \mathrm{x}$ milking respectively.

Milk yields in $2 \mathrm{x}$ and $3 \mathrm{x}$ daily milkings are not different.

Increasing the milking frequency, increases dry matter intake by the animals.

Animals on $2 x$ and $3 x$ milking frequencies had better efficiency of feed utilization than animals on $1 \mathrm{x}$ milking frequency.

\section{ACKNOWLEDGEMENT}

The authors wish to thank the Chairman of Small Ruminant Technical Committee of Teaching and Reaserch Farms of the Universitry of Agriculture Abeokuta, the personnel of the goat unit of the Farm and the College of Veterinary Medicine of the University.

Service (FMI). Great Britain. 33 pp.

Barnes, M.A., Pearson, R.E. and Luke-Wilson, A.J. 1990. Effect of milking frequency and selection for milk yield on productive efficiency of Holstein cows. J Dairy Sci, 73: 1603-1611.

Bar-Peled, U., Maltz, E., Bruckental, I., Folman, Y., 


\section{WILLIAMS, OSINOWO, SMITH, JAMES, IKEOBI, ONAGBESAN, SHITTU AND SOLOLA}

Kali, Y., Gacitau, H., Lehrer, A.R., Knight, C.H., Robinzon, B., Voet, H. and Tagari, H. 1995. Relationship between frequent milking or suckling in early lactation and milk production of high producing dairy cows. J Dairy Sci, 78: 2726-2736.

Bauman, D.E., Akers, R.M., Chapin, L.T., Tucker, H.A. and Convey, E.M. 1979. Effect of level of intake on serum concentrations of prolactin and growth hormone in lactating cows. J Dairy Sci, 62(Suppl. 1): 114 (Abstr.).

Bell, A.W. 1995. Regulation of organic nutrient metabolism during transition from late pregnancy to early lactation. J Anim Sci, 73: 2804-2819.

Blake, R.W. and Custodio, A.A. 1984. Feed efficiency: a composite trait of dairy cattle. $J$ Dairy Sci, 67: 2075 (Abstract).

Capote, J., Lopez, J.L., Caja, G. Peris, S., Arguello, A. and Darmanin, N. 1999. The effects of milking once or $2 x$ daily throughout lactation on milk production of Canarian dairy goats. In: Milking and milk production of dairy sheep and goats. Barillet, F. and Zervas, N.P. (ed.). Wageningen, Netherlands. pp. 267-273.

Carruthers, V.R., Davis, S.R., Bryant, A.M., Henderson, H.V., Morris, C.A. and Copeman, P.J.A. 1993. Response of Jersey and Freiesian cows to once a day milking and prediction of response based on udder characteristics and milk composition. J Dairy Res, 60: 1-11.

Chamberlain, A. 1989. Milk production in the tropics. Longman Scientific and Technical. England. 242 pp.

Davis, S.R., Farr, V.C. and Stelwagen, K. 1999. Regulation of yield loss and milk composition during once-daily milking: a review. Livest Prod Sci, 59: 77-94.

DePeters, E.J., Smith, N.E. and Acedo-Rico, J. 1995. Three or two times daily milking of older cows and first lactation cows for entire lactation. J Dairy Sci, 68: 123-132.

Duke, J.A. 1983. Handbook of energy crops Pennisetum purpureum K. Schumech. Centre for New Crops and Plant Products. Purdue University.

Erdman, R.A. and Varner, M. 1995. Fixed yield responses to increased milking frequency. $J$ Dairy Sci, 78: 1199-1203.

Hale, S.A., Capuco, A.V. and Erdman, R.A. 2003. Milk yield and mammary growth effects due to increased milking frequency during early lactation. J Dairy Sci, 86: 2061-2071.

Hansen, L.B., Young, C.W., Miller, K.P. and Touchberry, R.W. 1979. Health care requirements of dairy cattle. I. Response to milk yield selection. J Dairy Sci, 62: 1922.

Jurjanz, S., Laurent, F. and Graupner, M. 1993. Einfluß einer erhöhten Melkfrequenz auf die Milchzusammensetzung. Mh. Vet Med, 48: 631634.

Knight, C.H., Hillerton, J.E., Kerr, M.A., Teverson, R.M., Turvey, A. and Wilde, C.J. 1992. Separate and additive stimulation of bovine milk yield by the local and systemic galactopoietic stimuli of frequent milking and growth hormone. J Dairy Res, 59: 243-252.

Li, P., Rudland, P.S., Fernig, D.G., Finch, L.M.B. and Wilde, C.J. 1999. Modulation of mammary development and programmed cell death by the frequency of milk removal in lactating goats. $J$ Physiol, 519: 885-900.

Linzell, J.L. 1966. Measurement of udder volume in live goats as an index of mammary growth and function. J Dairy Sci, 49: 307-311.

Mocquot, J.C. 1978. Effects de l'omission reguliere et irreguliere d'une traite sur la production laitiere de la chevre. In: Proc. $2^{\text {nd }}$ Int. Symp. Milking Small Ruminants. Alghero. Italy. pp. 175-201.

Negrao, J.A., Marnet, P.G. and Labussiere, J. 2001. Effect of milking frequency on oxytocin release and milk production in dairy ewes. Small Ruminant Res, 39: 181-187.

Papachristoforou, C., Roushias, A. and Mavrogenis, A.P. 1982. The effect of milking frequency on milk production of Chios ewes and Damascus goats. Ann Zootech, 31: 37-46.

Peaker, M. 1990. The effect of raised intramammary pressure on mammary function in the goat in relation to the cessation of lactation. J Physiol, 301: 415-428.

Pearson, R.E., Fulton, L.A., Thompson, P.D. and Smith, J.W. 1979. Three times a day milking during the first half of lactation. J Dairy Sci, 62: 1941-1950.

Peel, C.J., Fronk, T.J., Bauman, D.E. and Gorewit, R.C. 1983. Effect of exogenous growth hormone in early and late lactation on lactational performance of dairy cows. J. Dairy Sci, 66: 776. (Abstr.).

Poole, D.A. 1982. The effects of milking cows

Archivos de zootecnia vol. 61, núm. 235, p. 464. 


\section{MILKING FREQUENCY, MILK YIELD AND DM INTAKE AND EFFICIENCY IN WAD GOATS}

three times daily. Anim Prod, 34: 197-201.

Royle, C., Gamsworth, P.C., McArthur, A.J. and Mepham, T.B. 1992. Effect of frequent milking on heart rate and other physiological variables in dairy cows. In: Int. Symp. Prospects for Automatic Milking, Hrdoc. Wageningen. The Netherlands. pp. 237.

Salama, A.A.K, Such, X., Caja, G., Rovai, M., Casals, R., Albanell, E., Marn, M.P. and Mart, A. 2003. Effects of once versus $2 x$ daily milking throughout lactation on milk yield and milk composition in dairy goats. J Dairy Sci, 86: 1673-1680.

Stelwagen, K. 2001. Effect of milking frequency on mammary functioning and shape of the lactation curve. J Dairy Sci, 84 (E. Suppl.): E204-E211.

Stelwagen, K., Davis, S.R., Farr, V.C., Prosser, C.G. and Sherlock, R.A. 1994a. Mammary epithelial cell tight junction integrity and mammary blood flow during an extended milking interval in goats. J Dairy Sci, 77: 426-432.

Stelwagen, K. and Knight, C.H. 1997. Effect of unilateral once or $2 x$ daily milking of cows on milk yield and udder characteristics in early and late lactation. J Dairy Res, 64: 487-494.

SYSTAT. 1992. Systat Computer Package. Version 5.02. Systat Inc. 1800. Sherman Ave. Evanston, IL. USA.

Tulloh, N.M. 1966. Physical studies of the alimentary tract of grazing cattle. IV. Dimensions of the tract in lactating and non-lactating cows. N.Z. J
Agric Res, 9: 999-1008.

Tyrrell, H.F., Brown, A.C.G., Reynolds, P.J., Haaland, G.I., Peel, C.J., Bauman, D.E. and Steinhour, W.D. 1982. Administration of bovine growth hormone to high yielding Holstein cows. I. Influence on in vivo energy metabolism. $J$ Dairy Sci, 65(Suppl. 1): 120 (Abstr.).

VanBaale, M.J., Ledwith, D.R., Thomson, J.M., Burgos, R., Collier, R.J. and Baumgard, L.H. 2005. Effect of increased milking frequency in early lactation with or without recombinant bovine somatotropin. J Dairy Sci, 88: 39053912.

Van der lest, R. and Hilerton, J.E. 1989. Short-term effects of frequent milking of dairy cows. $J$ Dairy Res, 56: 587-592.

White, A.W. 1989. Methods for improving feed utilization and lactation in ruminant animals. http://www.freepatentsonline.com/4801618. html (12/11/2007).

Wilde, C.J., Henderson, A.J., Knight, C.H., Blatchford, D.R., Faulkner, A. and Vernon, R.G. 1987. Effects of long-term 3x daily milking on mammary enzyme activity, cell population and milk yield in the goat. J Anim Sci, 64: 533-539. Wilde, C.J. and Knight, C.H. 1990. Milk yield and mammary function in goats during and after once-daily milking. J Dairy Res, 57: 441-447.

Wilde, C.J., Addey, C.V.P., Boddy, L.M. and Peaker, M. 1995. Autocrine regulation of milk secretion by protein in milk. Biochem J, 305: 51-58. 